Fabrice Larceneux \& Florence Benoit-Moreau \& Valérie Renaudin

F. Larceneux $\left(^{*}\right)$

Dauphine Recherches en Management (DRM, UMR 7088), Université Paris-Dauphine,

Place du Maréchal de Lattre de Tassigny, 75775 Paris Cedex 16, France

e-mail: fabrice.larceneux@dauphine.fr

\title{
Why Might Organic Labels Fail to Influence Consumer Choices? Marginal Labelling and Brand Equity Effects
}

\begin{abstract}
An organic label offers a market signal for producers of organic food products. In Western economies, the label has gained high recognition, but organic food still represents a small part of total food consumption, which raises questions about the label's efficacy. By considering organic labels a signal of quality for consumers, this article studies how this signal interacts with brand signals when both are visible to consumers, applying a cobranding framework. This research examines the moderating effect of the brand on organic label effects. In a $2 \times 2$ experimental design using real consumers $(n=122)$ in a shopping context, it found that, depending on brand equity, the marginal effect of organic labelling information in terms of perceived product quality vary. In particular, when brand equity is high (low), the organic label appears less (more) effective. However, regardless of the brand equity level, an organic label makes the environmentally friendly attribute salient, which has a positive impact on perceived quality. Pertinent implications for marketing and public policy are discussed.
\end{abstract}

Keywords Organic label, Brand equity, Label equity, Co-branding, Perceived quality, Environmentally friendly 
Modern global challenges, such as climate change and public health crises, push public authorities to defend and improve the long-term collective welfare of the populations for which they are responsible. To achieve this goal, sustainable consumption can be a critical contributor and encourage sustainable growth (Heiskanen and Pantzar 1997). The 1994 Oslo Symposium on sustainable consumption has established that the principles of democracy and the reality of control limitations demand that changes in consumption patterns be achieved not by force (e.g., bans) but rather through responsible consumer choices (Scammon and Mayer 1993) facilitated by the provision of independent information on markets. Because they allow for freedom of choice and avoid distorting market prices (Pearce 1991), labelling practices tend to be a preferred option to attain various objectives; for example, nutrition labels serve public health objectives (Mannell et al. 2006), and environmental labels aim to achieve ecological goals (see Koos 2011). In the food sector, official organic labels attempt to promote the development of organic farming and more sustainable consumption (Thøgersen 2000).

Yet current consumption lifestyles remain largely unsustainable, and progress toward sustainable consumption has been slow (Thøgersen 2004). Increases in organic consumption in many Western economies might have resulted from labelling strategies, but organic food still represents a small percentage of farming production in OECD countries (Hughner et al. 2007) and of consumption (Thøgersen 2010). For example, 25 years after the creation of the official organic label AB, only $2 \%$ of the total food market in France is organic. Discussions of labelling as a tool to encourage organic consumption thus require special attention to final demand-side aspects, that is, consumers' point of view and the reasons consumers do not buy, or even intend to buy, organic products (Beckman 2005). We therefore adopt the consumer perspective and deliberately leave aside other aspects, such as supply conditions (e.g., amount of dedicated land, retail availability).

Some research suggests that organic consumption might suffer from negative consumer perceptions, such as expensive perceived prices (Davies et al. 1995), lack of appeal (LataczLohmann and Foster 1997), poor trust in labels, or lack of perceived value (Makatouni 2002; We build on this latter argument: Strictly speaking, an organic label is a proof of certification that demonstrates compliance with specific requirements in production processes. But apart from a niche market of well-informed or concerned consumers, is what the label signals sufficient motivation to purchase more expensive products and thus to encourage sustainable consumption? If so, what conditions might make labels more or less effective? Do official labels offer enough added value, compared with other signals, such as trade brands? 
Furthermore, a more provocative approach to labels identifies them as cues to global quality, rather than just proof of certification. Therefore, we explore how consumers might infer subjective quality beliefs from the label, in line with a halo effect. Accordingly, we follow previous work that has shown that consumers often perceive organic products as healthier, tastier, safer, and supportive of local economy (Hughner et al. 2007; Lodorfos and Dennis 2008), as well as environmentally friendly. Zanolli and Naspetti (2002) find that health provides a primary consumption motive, even without proof that organic food is better for people's health. By providing information about several product attributes, an organic label thus competes with or complements other signals (or cues, in marketing terminology; Grunert 2005)

Therefore, this study makes several specific contributions. We consider how the context in which labels appear influences consumers' perceptions. As Thøgersen (2002) noted, if other relevant information competes for the consumer's attention, consumers may easily fail to notice relevant labels in the buying situation. In particular, we investigate the combined effect of two cues, the label and the trade brand, according to a cobranding theoretical framework (Geylani et al. 2008; Janiszewski and Van Osselaer 2000; Park et al. 1996; Rao and Ruekert 1994; Rao et al. 1999). We investigate the marginal value of an organic label that appears in combination with a brand, including whether that value varies for brands with high versus low equity. When a brand enjoys high brand equity, consumers feel confident that they know and can trust its product characteristics, so they may consider the organic label less useful.

This question has both political and managerial implications. Before companies adopt labelling strategies, they need assurance that the binding specifications will translate into effective commercial arguments and competitive advantage (Thøgersen 2002). Producers and retailers tend to adopt labelling strategies, which can be lengthy, costly, and difficult to reverse, only if they are expected to be profitable, especially compared with other signaling strategies, such as developing their own brand strategy or using advertising levers (Golan et al. 2000; Thøgersen 2000). This issue is particularly critical for retail brands, because large retail stores might provide effective sites for convincing people that choosing organic products is the best decision (Dytrtova 2008; Hofer 2000; Wier and Carlverley 2002). We thus explore the differences between strategies that signal quality with just the brand and those that add an official organic label. Do consumers perceive a significant difference? Is organic labelling a profitable option? 


\section{Literature Review and Hypotheses}

\section{Organic Labels as Signals of Product Quality}

Following an economic theoretical framework, public authorities allow producers to use organic labels to reduce the information asymmetry that exists when a producer has information about product quality that consumers lack. As Akerlof (1970) shows, if the seller cannot inform consumers of the superior quality of its product, it fails in the market, leaving only poor quality products (i.e., "lemons") available for purchase. To avoid this situation, the seller must bear a cost to signal its quality (Spence 1974): Labelling is an option for doing so.

Good products are generally viewed as those with higher quality. But are they really? What does quality exactly mean? Following Grunert (2005), we differentiate an economic perspective, which focuses on the "market signal of quality" and its ability to convey information about overall quality, from a marketing perspective, which explores the inferences that a consumer makes when confronted with an extrinsic cue to form judgments of overall quality and its dimensions. This differentiation echoes objective versus subjective dimensions of quality. For example, as a form of certification, an organic label is an economic signal, offering proof of objective quality because the product has been produced following environmentally friendly requirements. From a consumer-oriented perspective though, the label offers a cue that generates varied associations (Carpenter and Larceneux 2008) to help consumers make evaluations of overall quality, assuming they understand and trust the label (Koos 2011; Sønderskov and Daugbjerg 2010; Thøgersen 2004). In France, organic label recognition and knowledge is not an issue: $97 \%$ of French consumers recognize the organic label "AB" (Opinion Way 2010) and 80\% have eaten at least one organic product in 2011 (Ifop 2011). Because the label is issued by official third parties and backed by governments, it should be a well-trusted cue (Roosen et al. 2003). Even if the organic label is supposed to inform on environmental dimension, in line with various research (Golan et al. 2001; Nayga 1999; Jahn et al. 2005), results are not clear about the real overall perceived quality. Following Van Doorn and Verhoef (2011), in the specific case of virtue products, i.e. wholesome and nourishing, we suppose that consumers likely use the organic label to infer positively overall quality. As such, labelling policy would help to differentiate good from bad products. We postulate:

H1a: The presence of the organic label on a product positively influences consumers' perceptions of overall product quality.

From Holbrook and Corfman's (1985) and Zeithaml's (1988) research, we know that perceived overall quality represents the combination of consumers' perceptions of attributes. 
In food markets, Grunert et al. (1996) distinguish four attribute dimensions that determine consumers' product quality judgments: (1) sensory attributes, including taste, appearance, and smell, though for food, taste is dominant (Lodorfos and Dennis 2008; Thomson et al. 1994); (2) health attributes (e.g., food safety, positive effects on health); (3) process attributes, which assumes consumers' interest in process specifications (Lodorfos and Dennis 2008); and (4) convenience. The organic label informs consumers about specific characteristics, which lead to descriptive beliefs, but it also indirectly tells them about other attributes by generating inferential beliefs. Descriptive product beliefs derive from information provided by the cues in the shopping environment (Fishbein and Azjen 1975), which prompt a recalibration of the original information in more explicit terms (e.g., a "hand pressed" label on a bottle of wine generates the belief that the wine has been produced using traditional methods). The consumer constructs a belief based on a clear correspondence between the source and attribute information. In the specific case of the organic label, and given that the consumer knows, understands, and trusts the label, it logically prompts the belief that the product is produced using an environmentally friendly process, such as one without pesticides (Hughner et al. 2007; Roddy et al. 1996; Soler et al. 2002; Squires et al. 2001; Wandel and Bugge 1997). We thus predict:

$H 1 b$ : The presence of the organic label on a product makes consumers associate the product with descriptive belief of environmental friendliness.

Beyond descriptive beliefs, inferential beliefs might arise (Grunert, 2005). These beliefs occur through inferential processes (Van Birgelen et al. 2000), through an elaboration of meaning beyond that provided explicitly (Pinson 1986). Thus inferential beliefs are due to halo effects (Broniarczyk and Alba 1994) based on strong mental inter-attribute associations (Johnson and Levin 1985; Kardes 1988). Attribute associations are also the basic cause of the so-called "magic bullet" effect (Roe et al. 1999). For example, in a qualitative study, French people expressed their belief that organic salmon offered better quality in terms of taste and health (Beckman 2005), though neither of these benefits was certified by the label. Organic consumption research similarly has found that the main motives for consuming organic products include perceptions of superior taste (Hughner et al. 2007; Magnusson et al. 2003; Roddy et al. 1996; Schifferstein and Oude Ophuis 1998; Wolf McGarry et al. 2009) and health concerns (Chinnici et al. 2002; Huang 1996; Hughner et al. 2007; Hutchins and Greenhalgh 1995; Mondelaers et al. 2009a; Schifferstein and Oude Ophuis 1998; Tregear et al. 1994; Wolf McGarry et al. 2009; Zanolli and Naspetti 2002), though these benefits have not been proven (Hoefkens et al. 2009). Thus, we hypothesize: 
H1c: The presence of the organic label on a product causes consumers to associate the inferential beliefs of good taste (i) and reduced health risks (ii) with the product. Organic Labels as Signals of Quality in Competition with Others Little research has analyzed organic labels' efficiency in context (Anders and Moeser 2008; Thøgersen 2002; Thomson 1998), though multiple cues might inform consumers about product quality, especially in food markets (Grunert 1995). Among the various extrinsic cues, brands are fundamental to the consumer evaluation process (Dawar and Parker 1994; Rao et al. 1999). From a signaling perspective, brands provide signals of unobservable quality (Rao and Ruekert 1994; Rao et al. 1999; Wernerfelt 1988) that might complement or compete with organic labels in terms of their effects on product quality judgments (Gray-Lee et al. 1994). According to Koos (2011), research into the effect of a plurality of quality signals is desperately needed to understand labels' efficacy. This may contribute to the apparent contradiction that, although organic labels have high credibility and can influence consumer perceptions (Erdem and Swait 1998; Thøgersen 2000), even the most environmentally conscious consumers do not always choose products on the basis of their environmental features (Rokka and Uusitalo 2008; Thøgersen 2004; Thøgersen and Olander 2003). According to Hughner et al. (2007), a primary deterrent to their purchase is satisfaction with current food sources. Consumers might buy a nonorganic, brand name product if that brand conveys high overall quality. Therefore, attitudes toward a product should depend on its brand and the level of brand equity it attains.

Brand Equity and Label Equity: Cobranding and the Marginal Labelling Effect (MLE) Brand equity refers to "a set of brand assets and liabilities linked to a brand, its name and symbol, that add to or subtract from the value provided by a product or service to a firm and/or to that firm's customers" (Aaker 1991, p. 15). Building brand equity requires marketing actions; higher spending on reputation creates a more credible signal of quality for consumers (Erdem and Swait 1998; Ippolito 1990; Rao and Ruekert 1994). Keller (1993) proposes splitting brand equity into two dimensions, brand awareness and brand image, where the latter is based on associations or clusters of beliefs associated with the brand (Geylani et al. 2008). As a global signal of quality, a brand also serves as a cue for evaluating or predicting performance on a set of relevant attributes (Park et al. 1996), in parallel with the inferencemaking process for labels.

We propose that third-party labels constitute specific types of brands that cover different types of products that fit the required specifications. Similar to brand equity, we 
define label equity (see also Carpenter and Larceneux 2008) as awareness and a set of associations or beliefs that provide a strong, sustainable, differentiated advantage, compared with that achieved by unlabeled products. In this perspective, when a brand adds an organic label to its product packaging, the result is a type of cobranding. In a brand alliance, "two or more brand names are presented jointly to the consumer" (Rao et al. 1999, p. 259; Geylani et al. 2008); cobranding implies a physical integration of the two brands (Levin and Levin 2000). The cobranding framework can apply to different kind of alliances, such as a common presence on a packaging, joint advertising or promotion campaigns, sponsorship of sports activities, and so on (Lebar et al. 2005). It also can encompass the joint presence of a trade brand and an official label.

Cobranding aims to enhance both brands' equity through affect or association transfers (Kim et al. 1996, 1998), because "two brand names may provide greater assurance about product quality than one alone" (Park et al. 1996, p.454). However, brand equity transfers occur mainly when an individual brand cannot signal quality by itself (Rao and Ruekert 1994). Several research works examine cobranding efficiency (Geylani et al. 2008; Janiszewski and Van Osselaer 2000; Park et al. 1996). For example, Janiszewski and Van Osselaer (2000) demonstrate that two brand names compete (or interact) to predict product performance, rather than acquiring predictive value independently; that is, they do not necessarily join forces but can be redundant or detrimental. Park et al. (1996) demonstrate that cobranding by two favorably evaluated brands does not lead to a more favorably evaluated cobranded product, because of their redundancy and probably a ceiling effect. Therefore a brand with high equity has less to gain from an association with an organic label than one with less brand equity. Similarly, Mondelaers et al. (2009a) show that consumers prefer organic products over weak branded products but not over strong branded products. Thus, the effect of the organic label should depend on the equity of the associated brand, and it is more accurate to consider the marginal effect of the label (MLE), in addition to the brand, to estimate the usefulness of environmental labelling for a branded product. Hence, we hypothesize:

H2a: The impact of an organic label on perceived overall product quality is weaker when the original brand has high rather than low brand equity.

At the attribute level, Park et al. (1996) demonstrate the importance of brands' complementarity for effective alliances. Brands are complementary when they have a common set of relevant attributes but differ in their attribute salience or performance. In this case, consumers tend to align their evaluation of the attributes of the cobranded product with 
the most salient or highest performing partner. Therefore, brands truly join forces, through the alignment of the overall score with the top performer's evaluation. When two brands are evaluated favorably on the same attributes though, they offer redundant predictive information and are inefficient as cobranding partners: They would obtain the same evaluation even in a standalone scenario. Applying this reasoning, we predict that a brand with high brand equity triggers an image of high quality and stronger, more numerous associations. Central food associations, such as good taste and lower health risk, should be more salient and better evaluated for high equity brands. Then through the halo effect (Leuthesser et al. 1995), inferential beliefs such as environmentally friendly may also increase for a high equity brand compared with a low equity one. The complementarity between the label and the low equity brand in turn should be greater than that for the high equity brand and enhance perceptions of product attributes (good taste, reduced health risk, environmental friendliness) more. We hypothesize then that

$H 2 b$ : The impact of the organic label on the strength of a descriptive belief about environmental friendliness is weaker when the original brand has high rather than low brand equity.

H2c: The impact of the organic label on the strength of the inferential beliefs about good taste (i) and reduced health risk (ii) is weaker when the original brand has high rather than low brand equity.

Reinforcing the Salience of Environment Friendliness for Product Quality Judgments Even if consumers express environmental concerns (Alwitt and Pitts 1996), environmentally friendly features may remain peripheral if there is no personal threat (Thøgersen 2000), because they will not be integrated into the overall quality assessments in normal food product evaluations. Because of its associations with benefits such as taste, health, and concern for the environment (Hughner et al. 2007), the presence of an organic label should activate corresponding cues and make these attribute more salient to judgments of overall product quality.

According to the accessibility-diagnosticity model (Feldman and Lynch 1988; Herr et al. 1991), the likelihood that a piece of information is used as an input to a judgment depends on the accessibility and diagnosticity of this input, compared with that of alternative inputs. Considering its salience for the organic label, the environmentally friendly attribute becomes more accessible. The organic label, as a credible and certified quality signal, also should boost consumers' confidence in the information, which assures its diagnosticity of this attribute. We hypothesize: 
H3: An organic label significantly increases the influence of the environmentally friendly attribute in consumers' judgments of overall product quality.

\section{Field Study Methodology}

To test the different hypotheses, we conducted a between-subjects $2 \times 2$ experiment in which we manipulated brand equity (high versus low) and the labelling strategy (no label versus organic label).

\section{Product and Brand Manipulations}

Because realism is required for research on environmentally friendly choices (Rokka and Uusitalo 2008), we did our best to approximate real purchase conditions. Similar to Rao et al. (1999), we conducted our experiment near the checkouts of Monoprix retail stores. In addition, we manipulated differences in brand equity by using existing brands that, at the time of the study, used an organic labelling strategy. Based on observations in five retail stores across different product categories, we chose smoked salmon as the test category for several reasons. Salmon is an interesting case of organic food because consumers' demands might at least partly explain the development of salmon farming (Beckman 2005). In France, this product category includes a wide variety of positioning tactics (costs range from $3 €$ to $10 €$ ) and quality levels, and various brands and labels appear on shelves. Furthermore, taste, health and environmental issues are dimensions French consumers evoke when they assess quality of organic salmon (Beckman 2005). Although salmon was once a product consumed only on special occasions, it has become quite inexpensive and far more common.

In our experiment, 122 adult customers evaluated a salmon packaging, recruited right after they completed a checkout at a Monoprix store. We kept only salmon buyers who bought salmon at least once in the past year. They viewed one of four versions of our study stimuli, then answered a short questionnaire that contained the dependent variables. These stimuli featured full-scale, color copies of the original packaging of two real brands sold in the store (Labeyrie and Monoprix private label), each with an added organic label or not (see Appendix 1). Each respondent was randomly assigned to one of the four conditions (Appendix 2).

The low equity brand was the Monoprix private label "M"; this brand covers a wide range of products with mainstream positioning in terms of price, quality, and product features. Brand equity research often uses mainstream private labels as benchmarks to measure a national brand's equity (Kamakura and Russel 1993), and Grunert (2005) has noted that "the 
lack of a brand history and the historical association of retailer brands with generic and low price products results in consumers taking a retail brand as a cue indicating low rather than high quality.” Monoprix also is a good setting for this study because its private brand encompasses many products. For the high equity brand, we used the leading national brand, "Labeyrie". Neither brand had adopted a specific positioning in relation to a natural or environmentally friendly image.

Dependent Variables

We evaluated both perceived overall quality and three potential components of overall quality: an environmentally friendly process of production, perceived good taste, and perceived health risk. For the four dependent variables, we used single-item instruments on seven-point scales ranging from "fully agree" to "fully disagree." Respondents thus considered the following question: "Please indicate your degree of agreement with the following assertions: (1) This smoked salmon is of high quality, (2) This smoked salmon seems to have a better taste than others, (3) Eating this smoked salmon could carry a risk for my health, and (4) This smoked salmon seems to have been bred following an environmentally friendly process." We controlled for sociodemographic variables, purchase frequency in the product category, and frequency of store visits.

\section{Results}

\section{Manipulation Check}

To assess differences in perceived brand equity, we used price image, a traditional aggregate measure that assumes a brand with high equity can charge a price premium, all else being equal (Lassar et al. 1995). We employed two questions to determine an appropriate price range: "Below what price would you not buy this product?" and "At what price do you consider that this product is being sold at an excessive price?" The wide price range of $3 €$ to $10 €$ corresponded with actual prices in the store. Price image constitutes the average responses to these two questions, and our manipulation was successful: The image of the product price for the low equity brand $(M=2.6)$ was significantly lower than that for the high equity brand $(\mathrm{M}=4.1 ; t(12)=4.9, p<.001)$.

\section{Control Variables and Descriptive Statistics}

Gender $\left(\chi^{2}(3)=4.0, n s\right)$, age $\left(\chi^{2}(9)=10.6, n s\right)$, and familiarity with the label $\left(\chi^{2}(3)=5.6, n s\right)$ are equally distributed across groups, but purchase frequency is not $\left(\chi^{2}(3)=14.8, p=.002\right)$. 
Our filter question excluded any consumers who never bought salmon. We include this variable in our analysis to control for its effect. In our sample, $30 \%$ of the respondents were men; $24 \%$ were younger than 25 years, $60 \%$ between 26 and 60 years, and $15 \%$ were older than 60 years. The descriptive statistics (means and standard deviations) for the two conditions are in Table 1.

[Table 1 here]

Tests of H1: Organic Label as a Signal of Quality

In order to study the signaling effect of the organic label, a one way Anova is run with the perception on overall product quality as the dependent variable. As expected, we find a significant main effect of the label on overall product quality $\mathrm{F}(1,120)=7.8, \mathrm{p}=.007)$, in support of H1a. Test of means differences showed that the non-labelled product was rated significantly lower in quality $(m=4.7)$ than the organic labelled product $(m=5.5)$. As H1a is supported, we conclude that consumers use this specific cue to infer a better overall quality: they identify "good" products by means of an organic label. 
$\mathrm{H} 1 \mathrm{~b}$ and H1c suggest this label generates descriptive beliefs on environmentally friendly process and inferential beliefs on good taste and health risk. In order to test this impact on several correlated (the correlation between items such as good taste *environment friendly is $\mathrm{r}$ $=.50$.) dependent measures simultaneously, a multivariate analysis of variance (Manova) is used (Hair et al. 1995), with label and brand as independent categorical variables. A significant Box's M test indicates an equality of variance/covariance matrices of the multiple dependent variables across treatment groups. Non-significant Levene tests for each single dependent variable further confirm this condition.

A one way Manova on the three beliefs is significant $(\mathrm{F}(2,116)=8.7, \mathrm{p}<.001)$. Results reveal a strong main effect of the organic label on the descriptive belief regarding environmental care taken during production $(\mathrm{F}(1,118)=24.8, \mathrm{p}<.001)$. Labelled products are rated more environmentally friendly $(\mathrm{m}=4.7)$ than non-labelled products $(\mathrm{m}=3.0)$. It appears that consumers take the label into account and they transform the AB logo into more explicit beliefs, as reflected in the item environmentally friendly, thus improving the assessment of the labelled product on this dimension. Hence, the organic label seems to be an effective proofof-process cue for consumers.

Interestingly, as hypothesized, an inferential belief emerges: the belief in a good taste of the product appears significantly improved by an organic label $(\mathrm{F}(1,118)=17.4, \mathrm{p}=.008)$. Labelled products are expected to be more tasty $(m=4.7)$ than non-labelled products $(m=4.0)$. Although the organic label does not guarantee better taste, consumers significantly infer a better experience in consuming the labelled product. However, contradicting what we hypothesized, the health risk inferential belief does not differ significantly between treatment groups, perhaps because of the low initial level of perceived risk on non-labelled products. In this sense, the change in perception induced by the label might not be useful or significant, even if it seems appealing. Hence, $\mathrm{H} 1 \mathrm{~b}$ and $\mathrm{H} 1 \mathrm{c}(\mathrm{i})$ are validated.

Test of H2: Moderating Effect of Brand Equity and Marginal Labelling Effect

To test our moderation hypothesis, a $2 \times 2$ Anova is run and the interaction effect between brand and label is analyzed on overall quality. As expected, results show a significant interaction effect $(F(1,117)=22.3 ; p<.001)$ : the signalling effect of the organic cue depends on 
brand equity level. From a consumer perspective, the organic label does not improve beliefs about overall quality when the brand enjoys high equity $(\mathrm{m}=5.7)$, compared to the nonlabelled identical branded product $(m=5.9)$. That is, overall quality judgments with a high brand equity attain such high levels that the organic label cannot improve them any further. Conversely, the quality perception of a branded product with low brand equity $(\mathrm{m}=3.6)$ is strongly improved by a label $(\mathrm{m}=5.2, \mathrm{t}(58)=4.8 ;<.000)$. Finally, the overall quality assessment that both low and high equity brands attain when labelled is similar, and the marginal labelling effect is close to 0 (see Figure 1). Hence, as the interaction effect shows, the label is not a useful tool for brand with high equity, "Labeyrie" in our experiment, but it is for the Monoprix own brand "M". In other words, "good," i.e. organic, products are not always perceived as different from conventional products in terms of overall quality (figure 1). Hence, $\mathrm{H} 2 \mathrm{a}$ is supported.

[Table 2 and 3 here]

Similarly, a $2 \times 2$ Manova on the three beliefs show a marginally significant interaction effect $(\mathrm{F}(3,115)=3.1 ; \mathrm{p}=.079)$ on environmentally friendly perception. The effect of the organic label is significant for both types of brands. Regarding the brand with low equity, "M" is badly rated $(\mathrm{m}=2.4)$ and the label significantly improves this perception to $(\mathrm{m}=4.6$; $\mathrm{t}(58)=4.5, \mathrm{p}<.001)$. Similarly, as shown in Figure 2, the environmentally friendly dimension of the high brand equity "Labeyrie" $(\mathrm{m}=3.7)$ increases with the label $(\mathrm{m}=4.8, \mathrm{t}(60)=.5$, $\mathrm{p}=.013)$. However, this effect is weaker as the high equity brand is not perceived as a real non environmental brand $(\mathrm{m}=3.7)$, instead of the low equity brand $(\mathrm{m}=2.4, \mathrm{t}(58)=2.9, \mathrm{p}=.006)$. Noticeably, organic labelled "Labeyrie" $(\mathrm{m}=4.8)$ is identical as organic labelled "M" $(\mathrm{m}=4.6$, ns). This similar level reached by brands with the organic label is like a certain standardized level consumers have in mind. Hence, both the low and the high equity brand benefit from the organic label but, as the Anova test is significant, the former enjoys a stronger benefit and attains the same level as the latter on this descriptive belief.

Interestingly, we find a similar pattern of results for the inferential belief good taste as the one found with overall quality: the interaction effect $(F(3,115)=27.3 ; \mathrm{p}<.001)$ is the same and the organic label is not even marginally useful to reinforce this brand association for the high equity brand. The expected taste of "Labeyrie" is well evaluated $(\mathrm{m}=5.0)$ and not improved by the label $(m=4.9)$. However, the expected taste of "M" $(m=2.9)$ is significantly improved with 
the organic label $(\mathrm{m}=4.6, \mathrm{t}(58)=4.8 ; \mathrm{p}<.001)$. Therefore, an organic label allows "M" to reach the same expected taste as "Labeyrie." As there is no main effect from brand and label on health risk perception, we have not run the model on this dimension. We notice, though, that in case of low brand equity, the health risk perception is stronger for the non-labelled branded product $(\mathrm{m}=2.5)$ than for the organic branded product $(\mathrm{m}=1.6, \mathrm{t}(58)=2.6 ; \mathrm{p}=0.011)$, suggesting that, in such situation (and by extension in case of a health crisis), this label might turn out a relevant remedy. In case of high brand equity, the health risk perception is rated for the labelled product $(\mathrm{m}=2.0)$ no significantly different as or the non labelled product $(\mathrm{m}=1.7$, $\mathrm{t}(60)=1.3 ; \mathrm{p}=.203)$. Both brands ultimately reach the same level for the descriptive and inferential associations. Therefore we find support for $\mathrm{H} 2 \mathrm{~b}$ and $\mathrm{H} 2 \mathrm{c}(\mathrm{i})$.

[Figure 1, 2, 3 here]

Test of H3: Reinforcing the Importance of Environmentally Friendliness

$\mathrm{H} 3$ suggests that the environmentally friendly (EF) dimension contributes to the perception of overall quality only once the organic AB label shows and raises consumers' attention to this attribute. In order to test this, we run a 2 (label) $\times 2(\mathrm{EF})$ Anova on overall quality, where the continuous variable environmentally friendliness (EF) is dichotomized in two equivalent clusters in terms of respondents (48 rated EF $<4$ and 48 rated $\mathrm{EF}>4$ ). Results exhibit main effects of good taste $(\mathrm{F}(1,89)=24.3, \mathrm{p}<.001)$ and health risk $(\mathrm{F}(1,89)=15.0, \mathrm{p}<.001)$ on quality perception, when the brand is controlled $(\mathrm{F}(1,89)=19.9, \mathrm{p}<.001)$ as well as the label $(\mathrm{F}(1,89)=.4, \mathrm{~ns})$, but no direct effect of $\mathrm{EF}(\mathrm{F}(1,89)=.0$, ns $)$. However, the interaction between the organic label and the belief about environmental friendliness is marginally significant $(\mathrm{F}(1,89)=3.0 ; \mathrm{p}=.089)$. As hypothesized, this suggests that the environmentally friendly dimension influences judgments of overall quality only when an organic label appears on the package, making the attribute more salient. Hence, H3 is supported.

\section{Conclusion and Discussion}

The starting point for this research was the decision by public authorities to develop organic labels as instruments to encourage organic and thereby also a part of sustainable consumption. Although much research has studied the motivations for and deterrents to organic consumption, little work has investigated specific context-dependent impacts of the organic label or the conditions under which an impact is more likely to appear. We contribute to fill 
this gap by considering the joint use of an organic label and a brand name, which represents a realistic buying condition. We do not focus on the reasons why halo effects might exist, but rather on the consequences of the possible interaction between a label and other cues that signal quality. We investigate whether the organic label, as a signal of quality, competes with or complements other potential quality cues, such as the brand name. The combined presence of two signals resembles cobranding, so we use the framework of brand equity transfers through cobranding to discern the effect of the label, according to the MLE. Our $2 \times 2$ experiment was conducted among real consumers in an actual retail point of sale.

With this research, we have confirmed and qualified the relevance of the organic label. It boosts overall perceived quality and generates different product beliefs, including the descriptive belief that the product is environmentally friendly and the inferential belief that it offers good taste. However, in the studied case it did not affect health risk beliefs (except a weak influence in case of LBE products), perhaps because there have not recently been any crises involving the smoked salmon product category. In sum, we confirm an actual signalling effect, such that a more organic product can be differentiated from conventional (unlabelled) products. Hence, the organic label is a relevant market signal in the eyes of consumers.

The perceived overall quality assessment is apparently to a higher extent based on consumers' expectations regarding good taste than regarding health risk, which aligns with previous research. Without and organic label, consumers do not appear to perceive a significant link between environment friendliness and overall product quality in the analysed case. Hence, the environmentally friendly dimension seems not permanently inside consumers' attention and instead remains a peripheral attribute, or at least a dimension distinct from perceived quality, which might be more reflective of consumers' perceived direct benefits. The presence of an organic label is useful, among other things, because it enhances the salience of this dimension and invites consumers to use it when they form quality judgments.

In our realistic shopping context, we find that the interaction of the organic label and brand signals is significant; the marginal labelling effect is lower for both the overall perceived quality and the three specific beliefs when the product endorses a high equity brand rather than a low equity one. We thus confirm our hypothesis of a moderating effect of brand equity and the accuracy of the MLE proposition. In some cases, the marginal effect of the organic label when combined with a high equity brand is null. 
Theoretical Implications and Limitations

From a theoretical point of view, this research sheds light on an important determinant of label effectiveness, namely, the context of cues in which it appears. Although labels might appear to provide objective signals, with clear and homogeneous meanings, we show that the power of their message depends on the associated product brand. Hence, future research should consider other combinations of quality cues or other application contexts for organic or environmental labels.

With regard to the cobranding literature, we show that "co-cueing" is not necessarily a winning strategy for all partners. Rao and Ruekert (1994, p. 87) hold that "because brand names are valuable assets, they may be combined with other brand names to form a synergistic alliance in which the sum is greater than the parts." However, this synergistic effect does not always emerge, even if the alliance does not necessarily damage one partner. The marginal effect might be null, probably because the two contributors to a cobranding alliance provide redundant, rather than complementary, information. This research is in line with previous works on cobranding: First, information from cues, such as brands and labels, is not processed independently but rather in combination, such that they can compete with or influence the other's predictiveness (Janiszewski and Van Osselaer 2000). Second, complementarity between brands is essential for transfers to occur and to align cobranded products' attribute judgment with those of the top performer (Park et al. 1996). A brand with low brand equity has much more to gain from a partnership than a brand with high brand equity.

Further research should also examine the algorithm that describes the development of product beliefs. In particular, we have not taken into account the degree of certainty or uncertainty in attribute performance judgments (Geylani et al. 2008). The certainty of label beliefs might be higher, because it has been certified and thus provides a more credible signal than a brand.

This study only considers one category of products, described using only two brands. If the manipulated brands are very familiar to consumers, they might envisage other brands as well, such as the recently launched, high equity private-label brand Monoprix Gourmet, which promises quality similar to that of national brands. Our results also may be affected by the structure of competition in the studied market, the French salmon market. Many brands coexist, but other than Labeyrie, few are well-known or positioned on a specific promise. Labeyrie is a market leader, with a strong brand image on many different attributes. In addition, labelling induces a standard, a similar perceived quality level, even though brands 
seek to differentiate themselves. The results should therefore be replicated in a more sophisticated market, in which each brand takes a very specific positioning and only a few salient attributes.

Smoked salmon might be questioned as a non-typical organically labelled product. Hence, further research might replicate our study with products that represent different levels of organic typicality (e.g., raw versus processed products) and in different shopping contexts. Furthermore, with regard to the marginal labelling effect, we investigate three specific beliefs and overall perceived quality. Beliefs about other attributes, such as local production, could be influenced more directly by the label and might reveal a stronger effect even on high equity brands. It would also be interesting to consider dependent variables other than overall quality, such as choice or preference (Park et al., 1996) to ensure our results are not due to quality perception ceiling effects. Finally, this study could be replicated in different countries, where organic labels are presented differently and induce different perceptions or signal effects.

More generally, we suggest that research consider the interaction effect of labels with other signals of quality, such as warranty offers (Boulding and Kirmani 1993; Cooper and Ross 1985; Grossman 1981), advertising expenditures (Kirmani 1997; Kirmani and Wright 1989; Nelson 1974), store reputation (Rao and Monroe 1988), high market share (Hellofs and Jacobson 1999), or other labels, such as a possible $\mathrm{CO}_{2}$ footprint label. All these cues are likely to moderate the impact of the organic label.

Policy Implications

The intricacies of the process by which consumers make judgments about differentiated products create a challenge for the promotion of organic consumption. Public policy is often based on the assumption that more information is better (Grunert 2005), but sometimes officially provided information is not useful. By revealing a lower marginal impact of organic labels on high equity brands, we suggest that strong manufacturer brands, such as market leaders, innovators, and trendsetters, might be less interested in undertaking a labelling process, especially when labels mean external constraints without clear advantages. These brands must trade off between investments in quality signaling that might enhance brand equity directly (e.g., advertising, promotions) or in labelling. Furthermore, whereas investing in brand equity helps differentiate the firm from competitors, labelling tends to homogenize perceptions. Without regulations, most brands likely choose the most profitable approach, which generates a higher return on equity. Leading brands also act as referents, serve as role models for other companies, and exert financial and social power. If they do not label, they 
could undermine labelling strategies overall and slow the development of this political tactic. An example is for instance mentioned by Thøgersen (2002), regarding Ariel in Denmark, which did not want to apply for the Nordic Swan, although they qualified for it. Similarly, numerous prestigious Chateaux in the French wine industry follow the organic guidelines, but do not show the organic label on bottles.

Among consumers, brand discourse and brand quality provide powerful signals, even if they are not certified or issued by independent third parties. Still, organic labels can increase the impact of environmentally friendly beliefs on consumers' overall quality judgments by educating and sensitizing them to the importance of this point. Thus we offer four main recommendations for policy makers:

1. Continue consumer education efforts, following a learning process by explaining label issuance and certification, so consumers do not consider this information at the same level as brand-provided information and to avoid competition between the cues (Thøgersen 2002; Thøgersen et al. 2010).

2. Clarify the meaning of labels by reducing their complexity and polysemy. The objective of the organic label is clear and translates into precise requirements, yet it still induces inferential beliefs, which implies the meaning may be vague and redundant. Thus $80 \%$ of French people would like more information about the advantages and disadvantages of organic products (Ifop, 2011), which can lead to negative associations (e.g., health risks due to the lack of preservatives in organic products). If the meaning was clearer, labels could add complementary, focused information to brand information. One perspective is suggested by Mondelaers et al. (2009b) highlighting the contribution to the natural biodiversity as an advantage of organic products.

3. Rely on the environmentally friendly attribute, which becomes more salient in judgments of overall quality when an organic label appears on the product, which is good news for the efficacy of the label in terms of enhancing sustainable endeavours. In cases where the promise of environmental friendliness is not integrated into motivations to buy food, labels might focus more on the benefits for consumers. For example, policy makers could explore how to transform greater agro-biodiversity and natural biodiversity (Mondelaers et al. 2009b) into consumer benefits.

4. Find ways to convince high equity brands and leading industrial firms about the importance of labelling as a means to encourage organic consumption. The effect of a labelling strategy for high equity brands (e.g., large national brands) appears relatively 
weak. In contrast, for lower equity brands (secondary brands, regional names, brands of small and medium companies, some private-label brands), the MLE is much stronger and the organic label is more profitable. Policymakers should turn primarily to those actors, which seem to benefit from organic labelling more than leader national brands.

Along similar lines, signals currently compete with official organic or environmental labels, acting as free riders that exploit consumer preferences for organic products, as well as their lack of ability to discern differences in the labels. For example, some brands have developed their own specifications, using both visual (green packaging) and semantic ("more ecological," “100\% natural”) claims. These signaling strategies prompt ecological associations and may be greenwashing (Anstine 2007; Dahl 2010; Polonsky et al. 1998); they also worsen confusion about official labels (Boström and Klintman 2006). Regulations thus seem necessary to prevent certain halo effects but also clarify what an organic label actually conveys. 


\section{References}

Aaker, D. A. (1991). Managing brand equity, NY: The Free Press.

Akerlof, G. A. (1970). The market for "Lemons": Qualitative uncertainty and the market mechanism, Quarterly Journal of Economics, 84 , 488-500.

Alwitt, L. F., \& Pitts, R. E. (1996). Predicting purchase intentions for an environmentally sensitive product. Journal of Consumer Psychology, 5, 49-64.

Anders, S., \& Moeser, A. (2008). Assessing the demand for value-based organic meats in Canada: A combined retail and household scanner-data approach. International Journal of Consumer Studies, 32, 457-469.

Anstine, J. (2007). Organic and all natural: Do consumers know the difference? Journal of Applied Economics and Policy, 26, 1, 15-28.

Beckman S. C. (2005), Information, consumer perceptions, and regulations: the case of organic salmon. in Karup, Signe (Ed.), Environment, information and consumer behaviour, pp. 197-215. Chettenham, UK, Edward Elgar.

Boström, M., \& Klintman, M. (2006). State-centered versus non-state driver organic food standardization: A comparison of the US and Sweden. Agriculture and Human Values, 23, $163-180$.

Boulding, W., \& Kirmani, A. (1993). A consumer side experimental examination of signaling theory: do consumers perceive warranties as signals of quality. Journal of Consumer Research, 20, 111-123.

Broniarczyk, S. M., \& Alba, J. W. (1994). The role of consumers' intuitions in inference making. Journal of Consumer Research, 21, 393-407.

Carpenter, M., \& Larceneux, F. (2008). Label equity and the effectiveness of values-based labels: an experiment with two French Protected Geographic Indication labels. International Journal of Consumer Studies, 32, 499-507.

Chinnici G., D’Amico M. \& Pecorino B. (2002). A multivariate statistical analysis on the consumers of organic products. British Food Journal, 104, 187-199.

Cooper, R., \& Ross, T. W. (1985). Product warranties and double moral hazard. Rand Journal of Economics, 16 (Spring), 103-113.

Dahl, R. (2010), Green washing. Do you know what you're buying? Environment Health Perspectives, 118, 246-252.

Davies, A., Titterington A., \& Cochrane, C. (1995). Who buys organic food? A profile of the purchasers of organic food in Northern Ireland. British Food Journal, 97, 10, 17-23. 
Dawar, N. \& Parker, P. (1994). Marketing universals: The use of brand name, price and physical appearance and retailers' reputation as signals of product quality. Journal of Marketing, 58, 2, 81-95.

Dytrtova, K. (2008). Organic farming in the Czech Republic, 2006. Retrieved Nov 19, 2009, from http://www.organic-europe.net/country_reports/czech_republic/default.asp.

Erdem, T., \& Swait, J. (1998). Brand equity as a signaling phenomenon. Journal of Consumer Psychology, 7, 131-158.

Feldman, J. M. \& Lynch, J. G. Jr. (1988). Self-generated validity and other effects of measurement on belief, attitude, intention, and behaviour. Journal of Applied Psychology, $73,421-435$.

Fishbein, M., \& Ajzen, I. (1975). Belief, attitude, intention and behavior: An introduction to theory and research. Addison-Wesley, Reading, MA.

Geylani, T., Inman, J. J., \& Hofstede, F. T. (2008), Image reinforcement or impairment: The effects of co-branding on attribute uncertainty, Marketing Science, 27, 730-744.

Golan, E., Kuchler, F., \& Mitchell, L. (2000). Economics of Food Labelling. Economic research service, food and rural economics division, US Department of Agriculture. Agricultural Handbook, 793, December, 1-41.

Golan, E., Kuchler, F., Mitchell, L., Greene, C., \& Jessup, A. (2001). Economics of food labeling, Journal of Consumer Policy, 24, 117-184.

Gray-Lee, J. W., Scammon, D. L., \& Mayer, R. N. (1994). Review of legal standards for environmental marketing claims. Journal of Public Policy and Marketing, 13, 155-159.

Grossman, S. J. (1981). The information role of warranties and private disclosure about product quality. Journal of Law And Economics, 24, December, 461-483.

Grunert, K. G., (2005). Food quality and safety: consumer perception and demand. European Review of Agricultural Economics, 32, 369-391.

Grunert, K. G., Baadsgaard, A., Larsen, H. H. \& Madsen, T. K. (1996). Market orientation in food and agriculture. Boston: Kluwer Academic.

Hair, J. F., Anderson, R. E., Tatham, R. L., \& Black, W. C. (1995). Multivariate Data Analysis. $4^{\text {th }}$ edition. Prentice Hall, New Jersey.

Heiskanen, E., \& Pantzar, M. (1997). Toward sustainable consumption: two new perspectives. Journal of Consumer Policy, 20, 409-442.

Hellofs, L. L., \& Jacobson, R. (1999). Market share and customers' perceptions of quality: when can firms grow their way to higher versus lower quality. Journal of Marketing, 63, $1,16-25$. 
Herr, P. M., Kardes, F. R., \& Kim, J. (1991). Effects of word-of-mouth and product attribute information on persuasion: An accessibility-diagnosticity perspective. Journal of Consumer Research, 17, 454-462.

Hoefkens C., Verbeke W., Aertsens J., Mondelaers K., \& Van Camp, J. (2009). The nutritional and toxicological value of organic vegetables: Consumer perception versus scientific evidence. British Food Journal, 111, 1062-1077.

Hofer, K. (2000). Labelling of organic food products. In A. Mol, V. Lauber, \& D. Liefferink (Eds.), The voluntary approach to environmental policy. Joint environmental policy-making in Europe (pp. 156-191). Oxford University.

Holbrook, M. B., \& Corfman, K. P. (1985). Quality and value in the consumption experience: Phaedrus rides again. In J. Jacoby and J. C. Olson (Eds.), Perceived Quality: How Consumers View Stores and Merchandise (pp. 31-57). Heath, Lexington, MA: Lexington Books.

Huang, C. L. (1996). Consumer preferences and attitudes towards organically grown produce. European Review of Agricultural Economics, 23, 331-342.

Hughner, R. S., McDonagh, P., Prothero, A., Schulz, C. J. II, \& Stanton, J. (2007). Who are organic food consumers? A compilation and review of why people purchase organic food. Journal of Consumer Behaviour, 6, 94-110.

Hutchins, R. K., \& Greenhalgh, L. A. (1995). November/december organic confusion: sustaining competitive advantage. Nutrition \& Food Science, 6, 11-14.

IFOP (2011), Les français et l'agriculture biologique, sondage pour le WWF et Vrai ! Ippolito, P. M. (1990). Bonding and nonbonding signals of product quality. Journal of Business, 63, 41-60.

Jahn, G., Schramm, M., \& Spiller, A. (2005). The Reliability of Certification: Quality Labels as a Consumer Policy Tool, Journal of Consumer Policy, 28, 53-73.

Janiszewski, C., \& Van Osselaer, S. (2000). A connectionist model of brand-quality associations. Journal of Marketing Research, 37, 331-350.

Johnson, R. D., \& Levin, I. P. (1985), More Than Meets The Eye: The Effect of Missing Information on Purchase Evaluation. Journal of Consumer Research, 12, 169-177.

Kamakura, W. A., \& Russel, G. J. (1993). Measuring brand value with scanner data. International Journal of Research in Marketing, 10, 9-22.

Kardes, F. R. (1988). Spontaneous inferences processes in advertising: the effects of conclusion omission and involvement on persuasion. Journal of Consumer Research, 15, 225-233. 
Keller, K. L. (1993). Conceptualizing, measuring, and managing customer-based brand equity. Journal of Marketing, 57, 1-22.

Kim J., Lim J. S., \& Bhargava M. (1998). The role of affect in attitude formation: A classical conditioning approach. Journal of the Academy of Marketing Science, 26, 143-152.

Kim, J. A., Allen C. T., \& Kardes F. R. (1996). An investigation of the meditational mechanisms underlying attitudinal conditioning. Journal of Marketing Research, 33, $318-328$.

Kirmani, A., \& Wright, P. (1989). Money Talks: Perceived Advertising Expense and Expected Product Quality. Journal of Consumer Research, 16, 344-353.

Kirmani, A. (1997). Advertising Repetition as a Signal of Quality: if it's advertised too much something must be Wrong. Journal of Advertising, 26, 77-98.

Koos, S. (2011). Varieties of environmental labelling, market structures, and sustainable consumption across Europe: A comparative analysis of organizational and market supply determinants of environmental-labelled goods. Journal of Consumer Policy, 34, 127-151.

Lassar, W., Mittal, B., \& Sharma, A. (1995). Measuring customer-based brand equity. Journal of Consumer Marketing, 12, 4, 11-19.

Latacz-Lohmann, U., \& Foster, C. (1997). From "niche" to "mainstream" - strategies for marketing organic food in Germany and the UK. British Food Journal, 99, 275-282.

Lebar, E., Buehler, P., Keller, K. L., Sawicka, M., Aksehirli, Z., \& Richey, K. (2005). Brand equity implications of joint branding programs. Journal of Advertising Research, 45, 413425 .

Leuthesser, L., Kohli, C. S., Harich, K. R. (1995). Brand equity: the halo effect measure. European Journal of Marketing, 29, 4, 57-66.

Levin, I. P., \& Levin, A. M. (2000). Modeling the role of brand alliances in the assimilation of product evaluations. Journal of Consumer Psychology, 9, 43-52.

Lodorfos, G. N., \& Dennis, J. (2008). Consumers' Intent : In the Organic Food Market. Journal of Food Products Marketing, 14, 2, 17-38.

Magnusson, M. K., Arvola, A., Hursti, U., Aberg, L., \& Sjödén, P. (2003). Choice of organic food related to perceived consequences for human health and to environmentally friendly behavior. Appetite, 40, 109-117.

Makatouni, A. (2002). What motivates consumers to buy organic foodin the UK? Results from a qualitative study. British Food Journal, 104, 345-352.

Mannell, A., Brevard, P., Nayga, R. Jr., Combris, P., Lee R., \& Gloeckner, J. (2006). French consumers' use of nutrition labels. Nutrition \& Food Science, 36, 159-168. 
Mondelaers, K., Verbeke, W., \& Van Huylenbroeck, G. (2009a). Importance of health and environment as quality traits in the buying decision of organic products. British Food Journal, 111, 1020-1039.

Mondelaers, K., Aertens, J., \& Van Huylenbroeck, G. (2009b). A meta-analysis of the differences in environmental impacts between organic and conventional farming. British Food Journal, 111, 1098-1119.

Nayga, R. M. J., (1999). On consumers' perception about the reliability of nutrient content claims on food labels, Journal of International Food \& Agribusiness Marketing, 11, 4355.

Nelson, P. (1974). Advertising as Information. Journal of Political Economy, 83 (July-August), 729-754.

Park, C. W., Jun S. Y., \& Shocker A. D. (1996). Composite branding alliances: an investigation of extension and feedback effects. Journal of Marketing Research, 23, 453466.

Pearce, D. W. (1991). The Role of Carbon Taxes in Adjusting to Global Warming. Economic Journal, 101, 938-48.

Pinson, C. (1986). An implicit product theory approach to consumers' inferential judgments about products. International Journal of Research in Marketing, 3, 19-39.

Polonsky, M. J., Bailey, J., Baker, H., Basche, C., Jepson C., \& Neath, L. (1998). Communicating environmental information: Are marketing claims on packaging misleading? Journal of Business Ethics, 17, 281-294.

Rao, A. R., \& Monroe, K. B. (1988). The moderating effect of prior knowledge on cue utilization in product evaluations. Journal of Consumer Research, 15, 253-264.

Rao, A. R., \& Ruekert, R. W. (1994). Brand alliances as signals of product quality. Sloan Management Review, 36, 1, 87-97.

Rao, A. R., Qu, L., \& Ruekert, R. W. (1999). Signaling unobservable product quality through a brand ally. Journal of Marketing Research, 36, 258-268.

Roddy, G., Cowan, C., \& Hutchinson, G. (1996). Irish market. British Food Journal, 96, 4, $3-10$.

Roe, B., Levy, A. S., \& Derby, B. M. (1999). The impact of health claims on consumer search and product evaluation outcomes: results from FDA. Journal of Public Policy \& Marketing, 18, 89-105.

Rokka, J., \& Uusitalo, L. (2008). Preference for green packaging in consumer product choices - Do consumers care? International Journal of Consumer Studies, 32, 516-525. 
Roosen, J., Lusk, J.L., \& Fox, J.A. (2003). Consumer demand for and attitude toward alternative beef labelling strategies in France, Germany, and the UK. Agribusiness, 19, 77 90.

Scammon, D., \& Mayer, R. N. (1993). Environmental labelling and advertising claim: International action and policy issues. European Advances in Consumer Research, Provo UT: Association for Consumer Research, 1, 338-344.

Schifferstein, H. N. J., \& Oude Ophuis, P. A. M. (1998). Health-related determinants of organic food consumption in the Netherlands. Food Quality and Preference, 9, 119-133.

Soler, F., Gil, J. M., \& Sanchez, M. (2002). Consumers' acceptability of organic food in Spain: results from an experimental auction market. British Food Journal, 104, 670-687.

Sønderskov, K. M., \& Daugbjerg, C. (2010). Eco-labelling, the state and consumer confidence. Paper presented at the $60^{\text {th }}$ Political Studies Association Annual Conference, Edinburgh, UK.

Spence, M. (1974). Market Signaling. Harvard University Press, Cambridge.

Squires, L., Juric, B., \& Cornwell, T. (2001). Level of market development and intensity of organic food consumption: cross-cultural study of Danish and New-Zealand consumers. Journal of Consumer Marketing, 18, 392-409.

Thøgersen, J. (2000). Psychological Determinants of Paying Attention to Eco-Labels in Purchase Decisions: Model Development and Multinational Validation. Journal of Consumer Policy, 23, 285-313.

Thøgersen, J. (2002). Promoting green consumer behavior with eco-labels. In T. Dietz \& P. Stern (Eds.), New tools for environmental protection: Education, information, and voluntary measures (pp. 83-104). Washington DC: National Academy Press.

Thøgersen, J., \& Olander, F. (2003). Spillover of environment-friendly consumer behaviour. Journal of Environmental Psychology, 23, 225-236.

Thøgersen, J. (2004). A cognitive dissonance interpretation of consistencies and inconsistencies in environmentally responsible behavior. Journal of Environmental Psychology, 24, 93-103.

Thøgersen, J. (2010). Country differences in sustainable consumption: The case of organic food. Journal of Macromarketing, 30, 171-185.

Thøgersen, J., Haugaard, P., \& Olesen, A. (2010). Understanding consumer responses to ecolabels. European Journal of Marketing, 44, 1787 - 1810.

Thompson, G. D. (1998). Consumer demand for organic foods: what we know and what we need to know. American Journal of Agricultural Economics, 80, 1113-1118. 
Thomson, K. H., Haziris, N., \& Alekos, P. (1994). Attitudes and food choice behavior. British Food Journal, 96, 9-13.

Tregear, A., Dent, J. B., \& McGregor, M.J. (1994). The demand for organically grown produce. British Food Journal, 96, 4, 21-25.

Van Birgelen, M., de Ruyter, K., \& Wetzels, M. (2000). The impact of incomplete information on the use of marketing research intelligence in international service settings: an experimental study. Journal of Service Research, 2, 372-387.

Van Doorn, J., \& Verhoef, P. (2011). Differences in Willingness to Pay for Organic Products between Virtue and Vice Food, International Journal of Research in Marketing, 28, 167 180.

Wandel, M., \& Bugge, A. (1997). Environmental concern in consumer evaluation of food quality. Food Quality and Preference, 8, 19-26.

Wernerfelt, B. (1988). Umbrella branding as a signal of a new product quality: an example of signaling by posting a bond. RAND Journal of Economics, 19, 458-466.

Wier, M., \& Calverley, C. (2002). Market potential for organic foods in Europe, British Food Journal, 104, 45-62.

Wolf McGarry, M., Butler, L. J., Martin, A. J., \& Foltz, J. D. (2009). Factors influencing the purchase decision for milk labelled rBST-free and organic. Journal of Food Distribution Research, 40, 187-191.

Zanolli, R., \& Naspetti, S. (2002). Consumer motivations in the purchase of organic food. British Food Journal, 104, 643-653.

Zeithaml, V. A. (1988). Consumer perceptions of price, quality and value: a means end model and synthesis of evidence. Journal of Marketing, 52, July, 2-22. 
Appendix 1 Packaging showed to respondents and questionnaire

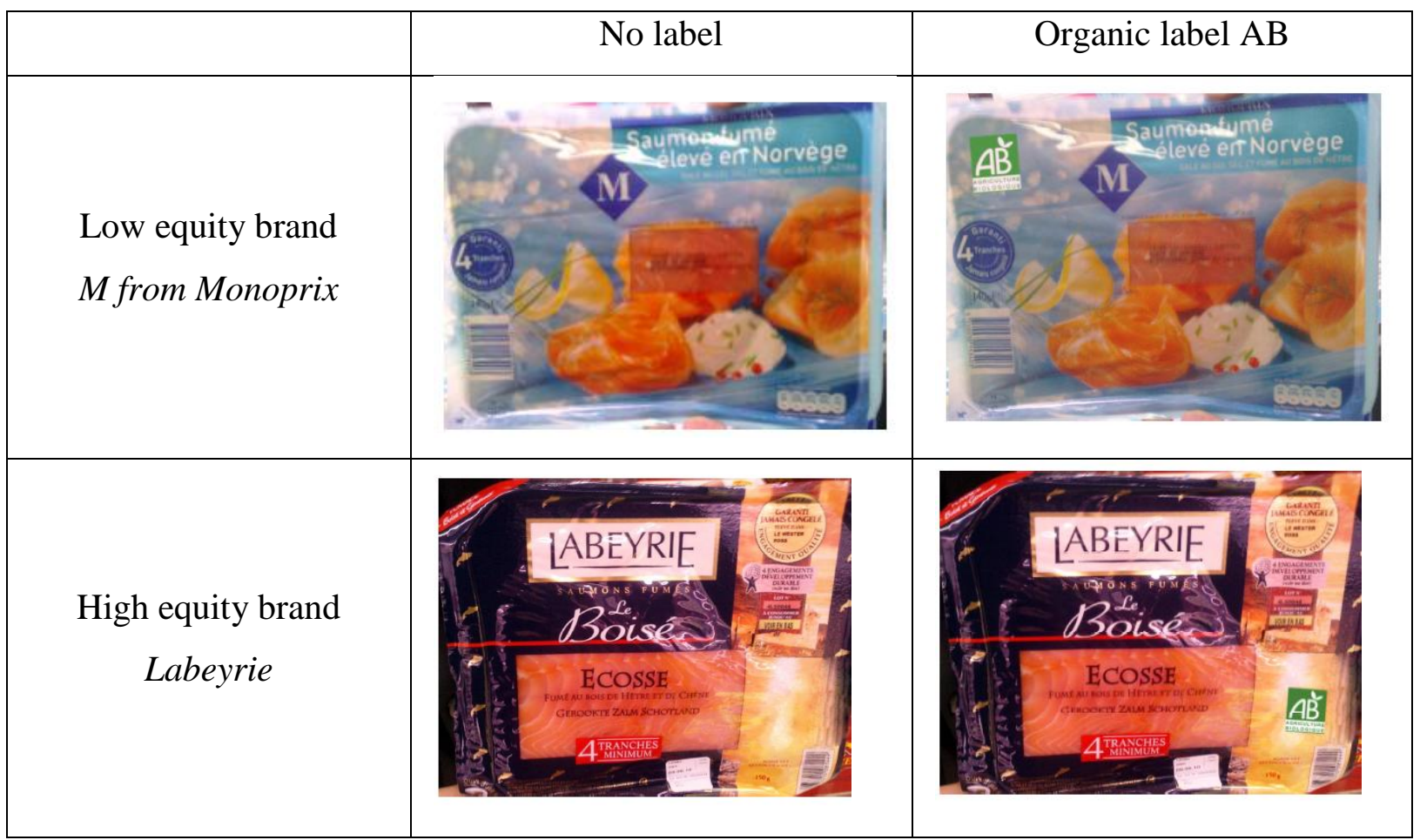

Ps.: Ecosse means Scotland in French

Appendix 2 Split of respondents across experimental treatments

\begin{tabular}{|c|c|c|c|}
\cline { 2 - 4 } \multicolumn{1}{c|}{} & No label & Organic label AB & Total \\
\hline $\begin{array}{c}\text { Low equity brand } \\
\text { M from Monoprix }\end{array}$ & 30 & 30 & 60 \\
\hline $\begin{array}{c}\text { High equity brand } \\
\text { Labeyrie }\end{array}$ & 30 & 32 & 62 \\
\hline Total & 60 & 62 & 122 \\
\hline
\end{tabular}


Table 1 Pairwise comparisons of quality perceptions and price image between the two labelling conditions

\begin{tabular}{|c|c|c|c|}
\hline \multirow[b]{2}{*}{ Dependent Variables } & \multicolumn{2}{|c|}{ Labelling } & \multirow[b]{2}{*}{$\begin{array}{l}\text { Significant } \\
\text { Difference }\end{array}$} \\
\hline & $\begin{array}{c}\text { Standard Label } \\
\quad \mathrm{N}=30\end{array}$ & $\begin{array}{c}\text { Organic } \\
\text { Label } \\
\mathrm{N}=30\end{array}$ & \\
\hline Overall quality & $\begin{array}{c}4.73 \\
1.6\end{array}$ & $\begin{array}{c}5.45 \\
1.3\end{array}$ & $t(120)=2.7 p=.007$ \\
\hline Good taste & $\begin{array}{c}3.95 \\
1.8\end{array}$ & $\begin{array}{l}4.74 \\
1.75\end{array}$ & $t(120)=2.6 p=.009$ \\
\hline Health risk & $\begin{array}{l}2.10 \\
1.65\end{array}$ & $\begin{array}{l}1.83 \\
1.04\end{array}$ & $N S$ \\
\hline Env. friendly & $\begin{array}{c}3.05 \\
1.9\end{array}$ & $\begin{array}{c}4.71 \\
1.7\end{array}$ & $t(120)=4.9 p<.001$ \\
\hline Price image & $\begin{array}{l}2.9 \\
1.6\end{array}$ & $\begin{array}{l}3.8 \\
1.9\end{array}$ & $t(120)=3.1 p=.002$ \\
\hline
\end{tabular}

Notes: Top value in each cell is the mean; bottom value in italics is the standard deviation.

Table 2 Pairwise comparisons of quality perceptions and price image between the two labelling conditions for low and high brand equity products

\begin{tabular}{|c|c|c|c|c|c|c|}
\hline \multirow[b]{2}{*}{ Dependent variables } & \multicolumn{2}{|c|}{ Low Brand Equity } & \multirow[b]{2}{*}{$\begin{array}{l}\text { Significant } \\
\text { Difference }\end{array}$} & \multicolumn{2}{|c|}{ High Brand Equity } & \multirow[b]{2}{*}{$\begin{array}{l}\text { Significant } \\
\text { Difference }\end{array}$} \\
\hline & $\begin{array}{l}\text { Standard Label } \\
\mathrm{N}=30\end{array}$ & $\begin{array}{c}\text { Organic } \\
\text { Label } \\
\mathrm{N}=30\end{array}$ & & $\begin{array}{c}\text { Standard Label } \\
\mathrm{N}=30\end{array}$ & $\begin{array}{c}\text { Organic } \\
\text { Label } \\
\mathrm{N}=32\end{array}$ & \\
\hline \multirow{2}{*}{ Overall quality } & 3.60 & 5.23 & \multirow[t]{2}{*}{$t(58)=4.8 p<.001$} & 5.87 & 5.65 & \multirow[t]{2}{*}{ NS } \\
\hline & 1.2 & 1.3 & & 1.13 & 0.92 & \\
\hline \multirow{2}{*}{ Good taste } & 2.87 & 4.60 & \multirow[t]{2}{*}{$t(58)=4.6 p<.001$} & 5.03 & 4.87 & \multirow[t]{2}{*}{ NS } \\
\hline & 1.07 & 1.75 & & 1.09 & 1.04 & \\
\hline \multirow{2}{*}{ Health risk } & 2.50 & 1.57 & \multirow[t]{2}{*}{$t(58)=2.6 p=.011$} & 1.70 & 2.09 & \multirow[t]{2}{*}{ NS } \\
\hline & 1.65 & 1.04 & & 1.09 & 1.04 & \\
\hline \multirow{2}{*}{ Env. friendly } & 2.4 & 4.60 & \multirow[t]{2}{*}{$t(58)=4.5 p<.001$} & 3.73 & 4.81 & \multirow[t]{2}{*}{$t(60)=.5 p=.013$} \\
\hline & 1.07 & 1.75 & & 1.09 & 1.04 & \\
\hline \multirow{2}{*}{ Price image } & 2.1 & 3.15 & \multirow[t]{2}{*}{$t(58)=2.9 p=.005$} & 3.65 & 4.50 & \multirow[t]{2}{*}{$t(60)=1.9 p=.058$} \\
\hline & 1.1 & 1.6 & & 1.09 & 1.04 & \\
\hline
\end{tabular}

Notes: Top value in each cell is the mean; bottom value in italics is the standard deviation.

Table 3 Direct and Interaction Effects of Brand and Labelling on Quality Perceptions. Anova and Manova Results

\begin{tabular}{|c|c|c|c|c|c|c|c|c|c|}
\hline & Univariate & $\begin{array}{l}\text { Multivariate } \\
\text { M-Box }=9.8\end{array}$ & & & & & & & \\
\hline & $\begin{array}{l}\text { Overall } \\
\text { Quality }\end{array}$ & $\begin{array}{c}\text { Wilk's } \\
\text { Lambda }\end{array}$ & $\begin{array}{c}\text { Effect } \\
\text { size }\end{array}$ & $d f$ & F value & Sig. & $\begin{array}{l}\text { Good } \\
\text { Taste }\end{array}$ & $\begin{array}{c}\text { Health } \\
\text { Risk }\end{array}$ & $\begin{array}{c}\text { Envir. } \\
\text { Friendly }\end{array}$ \\
\hline Brand & $\begin{array}{l}<.001 \\
(.261)\end{array}$ & .807 & .193 & $3 / 115$ & $9.179^{\mathrm{a}}$ & $<.001$ & $\begin{array}{l}<. .501 \\
(.168)\end{array}$ & $\begin{array}{c}.5 \\
\mathrm{~ns} \\
(.003)\end{array}$ & $\begin{array}{l}.017 \\
. .048)\end{array}$ \\
\hline & 9.2 & & & & & & 8.8 & 1.3 & 25.8 \\
\hline Organic label & $\begin{array}{l}<.001 \\
(.073)\end{array}$ & .782 & .218 & $3 / 115$ & 10.661 & $<.001$ & $\begin{array}{c}.004 \\
(.105)\end{array}$ & $\begin{array}{c}\mathrm{ns} \\
(.011)\end{array}$ & $\begin{array}{l}<.001 \\
(.175)\end{array}$ \\
\hline Brand * Organic label & $\begin{array}{l}22.3 \\
<.001 \\
(.160)\end{array}$ & .798 & .202 & $3 / 115$ & $9.722^{\mathrm{a}}$ & $<.001$ & $\begin{array}{c}27.3 \\
<.001 \\
(.201)\end{array}$ & $\begin{array}{c}8.0 \\
.005 \\
(.056)\end{array}$ & $\begin{array}{c}3.1 \\
. \mathbf{0 7 9} \\
(.026)\end{array}$ \\
\hline
\end{tabular}

Notes: For the univariate data, the top value is the $F$-value, and the bottom value in brackets is the effect size $\left(\right.$ eta $\left.{ }^{2}\right)$. Levene St. $=2.4(\mathrm{~ns})$ for taste and .7 (ns) for environment. 
Figure 1 The interaction of brand equity and labelling effects on consumers' perception of overall quality

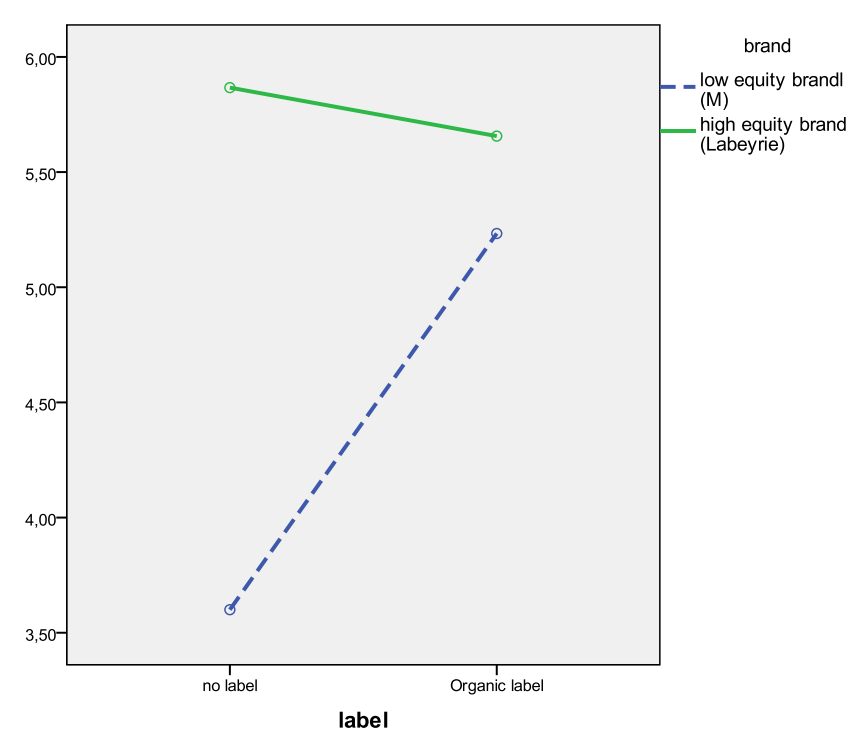

Figure 2 The interaction of brand equity and labelling effects on consumers' perception of good taste

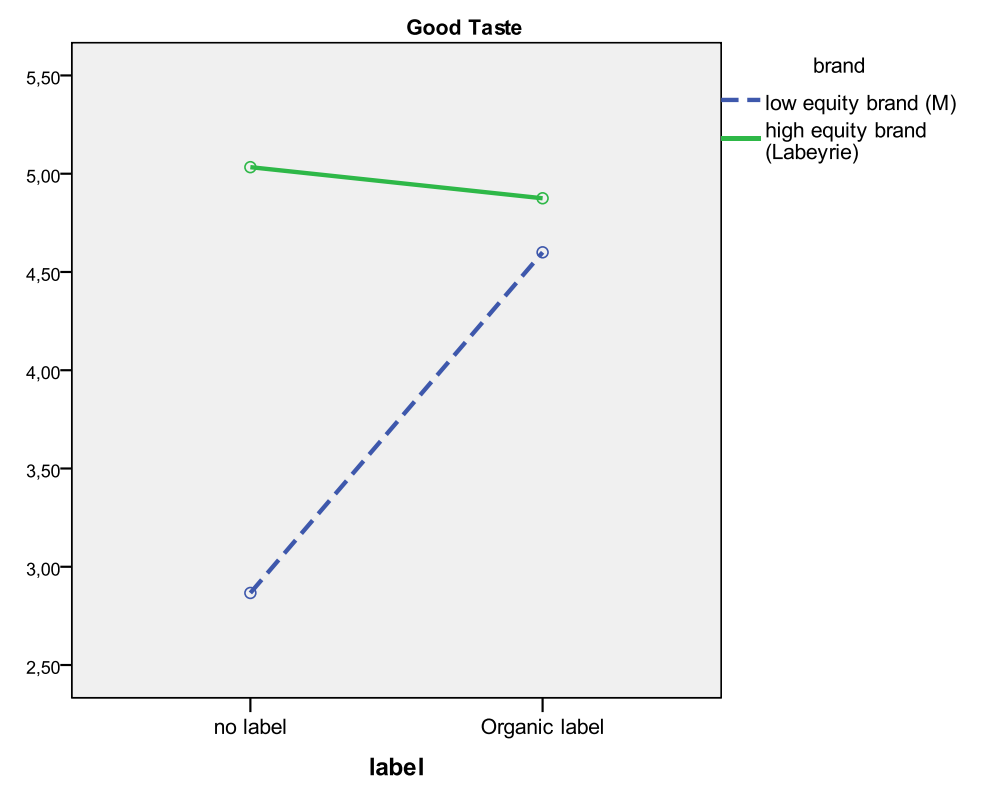


Figure 3 The interaction of brand equity and labelling effects on consumers' perception of environment friendliness

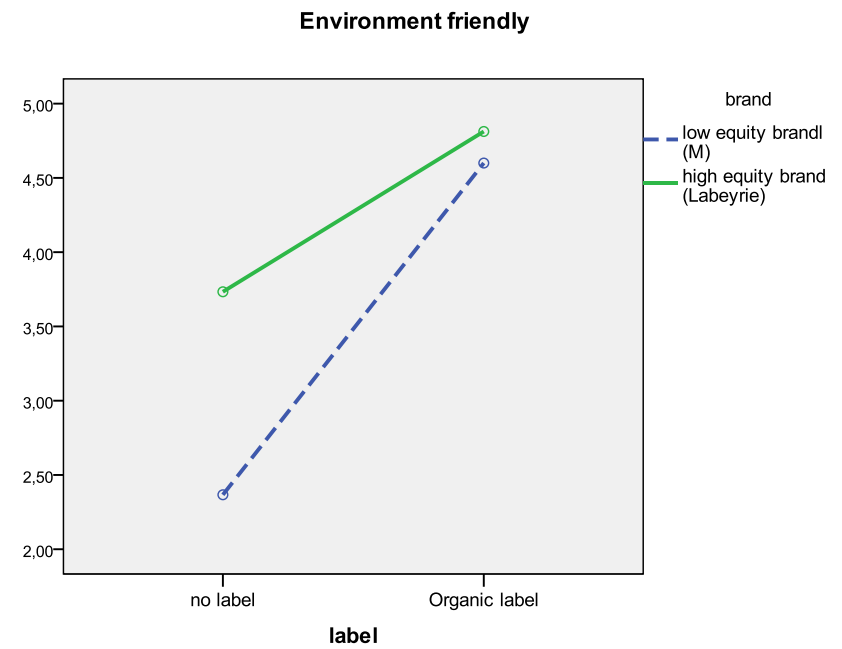

